\title{
Far right political stances: the same trend in Georgia?
}

\section{Introduction}

Nowadays, the study of the new far right social movements and political parties is becoming more and more popular. The primary reason for this can be explained with their growing electoral support and success. The experience of European countries shows that some of these groups have managed to become the government coalition member or created a new political agenda (Mudde, 2017: 5). Approximately the similar trends have been observed in Georgia which independent statehood has been around for three decades. The principled foreign policy course of European integration is recognized at the constitutional level (The Constitution of Georgia, Article 78, 1995). During the rise of Europeanization and the European lifestyle, ultra-nationalist forces are becoming active in Georgia (Wales, 2017). They are in formation process and have less public visibility, though they may echo the political stances of some citizens. Although recent public opinion polls show that more than $70 \%$ of population supports Euro-Atlantic foreign course of the country, still anti-European sentiments appears (Results of Public Opinion Polls in Georgia, 2019). As there is no successful experience of such political forces in Georgia, it is not easy to characterize their political positions and values. In this point of view, it is interesting to set up the major features of far right movements based on the contemporary experience of Georgia.

As the goal of the study is to determine how relevant European understanding of far right with the similar movements' political positions in Georgia is, it is essential to choose theory of radical/extreme/far right that meets the context of Georgia. Studying the issue, scholars usually focus on political parties and movements that avowed state already mentioned political positions. While in some European countries the tradition of far right has been around for several decades (Taggart, 1995: 34), Georgia, with its Soviet past, has the history of independence only from 1991. On the one hand, under the influence of Europeanization, it still remains the part of the wave, and on the oth-

\footnotetext{
* Correspondence address: 8 Ilia Chavchavadze Avenue, Tbilisi, 0179, Georgia, Tbilisi State University, Academic Building N6, e-mail: sandro.tabatadze010@sps.tsu.edu.ge.
} 
er hand, the crisis of legitimization of political system is also emerging (Nodia, Scholtbach, 2006: 30). In the wake of turbulent political landscape and non-inclusive economic growth, the country faces a serious problem of emigration: $2.5 \%$ of the population leaves it annually (Geostat, 2019). The outcome of the challenges has been reflected in various forms, including the activation of nationalist forces. Their political messages stress threats of the disappearance of family values and traditions by the political West that supports LGBT community (Roth, 2019). Nevertheless, in the party spectrum, only conservative, but not far right, groups are on the stage, which can be explained with turbulent party landscape. Thus, nowadays in Georgia, the forces expressing ultra-nationalistic messages are not parties, but movements and some of them informal groups.

The most visible is Georgian March officially founded in 2017, occasionally making radical political statements and holding demonstrations (Stephan, 2018). They mostly support anti-immigration and anti-LGBT policies, sharing pro-Church (Orthodox Christian) positions rejecting Western anti-religion propaganda. In 2018, the leaders (Sandro Bregadze and Gia Korkotashvili) of the movement declared to form national patrol against illegal immigrants (The anatomy of Georgian neo-Nazism, 2018). Interestingly, that in April 2019, Georgian March announced that the new, nationalistic political party can be merged that would be similar to Marine Le Pen's National Rally and would support to write Georgian ethnicity in Georgian citizens passports (Georgian farright groups reach agreement about forming new political party, 2019).

Another distinguished movement is Georgian National Unity that is friendly with Georgian March during demonstrations. Founded in 2016 as non-governmental organization, it has its leader and chancellor and uses black antlers as the symbol instead of swastika (Who threatens to create the civilian guard, 2019). During the Family Purity Day (against the international day of Homophobia, Transphobia, Biphobia) founded by Georgian Orthodox Christian Church, one of the protesters, Beka Lolashvili, said to the journalist that their movement ideology is "Georgian Fascism" (Member of $\mathrm{Na}$ tional Unity: We are Georgian fascists, 2018). Also, the leader of the movement, Giorgi Chelidze, declared that they support fascism and national-socialism. He also stressed that their organization would form the army of black armbands who will use different types of weapons and firearms. In addition, as Chelidze assumes, they have strict rules and use Fascist greetings (How women are accepted into the Georgian fascist organizations and where they are forbidden to love, 2018). Nowadays, he is in prison on charges of illegal possession of firearms and ammunition (13 lawyers are defending the leader of National Unity, 2018).

Anti-liberals as a Facebook group was founded in 2016. Citizens who share the similar political positions and values are joined in the group. The social media platform is private and claims that abusing the Orthodox Christian religion is inadmissible. In 2017, they made page named as Anti-liberal club that usually posts news connected to LGBT community rights, rising numbers of immigrants, importance of maintaining Christian 
and family values (Anti-liberal club, 2019). Most of the posts are made by Alt-Info that usually writes about the anti-political correctness, anti-abortion, anti-LGBT, anti-immigration issues (Alt-Info, 2019). Another, but informal, underground group is Edelweiss whose members meet and share anti-system views. Most of them are young and rarely emerging at public places. The group was founded in 2015 and they participated in September 27, 2016 demonstration against immigrants on Agmashenebeli Avenue. The rally participants shouted repetitively: "Georgia for Georgians" (The EMC responds to the violence on September 27 by ultranationalist groups, 2016), which reveals xenophobic sentiments. The social media page of Edelweiss protested "the existence of Turkish and Arab bar brothels where Georgian girls work" (Neo-Nazis march in Tbilisi - symbol of white nationalism, 2016). Although these movements have not institutionalized yet, the rise of the similar sentiments in Europe and the Europeanization of Georgia itself can establish the fertile ground for ultra-right positions. It is possible for them to become more influential social movement or political party that increases their chances at 2020 parliamentary election with the lowest natural threshold. Hence, we believe it is noteworthy to study political positions of these four movements. First of all, this allows us to characterize their political visions at the formation level and compare it with their further development. Moreover, it is interesting how congruent Georgian experience with understanding of far right in Europe is.

The article is divided into three parts. The first presents the theoretical framework and research methodology, the second overviews the recent political features of Georgia and the third part presents the results of the research.

\section{Theoretical framework and methodology}

There are active discussions about "right-wing radicalism", "right-wing extremism" and "far right" in contemporary social and political sciences. It can be said that the major challenge for scholars is to select the appropriate term and serious debates go on about the concept that meets the content of ultra-nationalism. There have been several empirical works on the issue over the last two decades (Koopmans, 1997: 149-164; Rydgren, 2005: 413-437; Von Beyme 2007: 1-18). However, as Paul Hainsworth points out the discussion about the term is delayed as these political forces, in some cases, are already government coalition members of European countries. The author stresses that the universal understanding of the concept has been disappearing (Hainsworth, 2008: 4). Cas Mudde believes that nowadays right-wing extremism is more socio-political jargon and has no clear definition (Mudde, 1996: 205). According to Roger Eatwell, it is a convenient, but flawed report (Eatwell, 2003: 11). These academic debates about the notion may continue perennially, unless we focus on the content and characters of the term itself. In this point of view, we can distinguish Anglo-Saxon and German schools of understanding of the right-wing. In the first case, radical and extremists political right are 
synonyms, the margins between them does not occur and, in general, this understanding means opposition platform to liberal democracy and globalism. The German school distinguishes right-wing extremism and radicalism. The first type, extremism, is based on the counter-vision of constitutional democracy and may resemble the well-known concept of friend-enemy in political theory. For the second type, radicalism, it has intermediate location between democracy and extremism and, therefore, this political platform stays in the democratic framework (Ivaldi, 2004). We can assume that the major difference between German and Anglo-Saxon schools stems from the Nazi background. The first one sees a clear difference between anti-system extremism and anti-government radicalism, while the second focuses of any opposition to liberal democratic regime.

One of the first scholars interested in the origins of the far right political forces was Piero Ignazi. The representative of German school, in his article "Silent Counter-Revolution" outlined the four key reasons for strengthen radical right: neoconservative cultural character, polarization, crisis of legitimacy and anti-migration policy (Ignazi, 1992: 3-34). The author believes that the growing public dissatisfaction with Post-materialistic "new politics" has transformed into the neoconservative cultural character that largely based on the principles of anti-minority and strong law and order. Ignazi points out that polarization of party politics and crises of legitimacy strengthened aggressive groups, focusing on anti-immigration and xenophobic political messages. At the same time, democracy has failed to respond and this process became "silent counter-revolution" expressed in right-wing radicalism. The author assesses the socio-political shifts in Western European countries in 1980s. As Ignazi points out, before 1980s far right has been the synonymous of neo-Nazi (Ignazi, 2003: 1). That is why he also differentiates between the groups with Nazi political experience and new radical right-wing movements. We can conclude that the major findings of the author caused the further interest on the issue and development of new research fields. However, the goal of that study covers different historical and geographical areas and is less relevant to use as the modern understanding of far right. In addition, the variables of that research are more likely proxies for far right politics more than basic characteristics.

Another noteworthy theory has been developed by Gilles Ivaldi. He identifies four main components of far right: negative attitudes toward immigration, authoritarian trends, economic protectionism and anti-systemic populism (Ivaldi, 2004). The author draws on the experience of the Anglo-Saxon school as he does not differentiate the radical and extremist positions. Although the criteria presented by Ivaldi can be used to characterize the political positions of modern far right, the understanding of the concept pose a number of questions. First of all, economic protectionism can be characteristic of any conservative or social-democratic government too, and labelling it definitely as far right makes it less valid. In addition, for the author, the far right political party or movement should share all four of these components that limit the content of the term, focusing only on these criteria. Also, it is unclear what kind of positions move- 
ment share if it satisfies only two or three components from this list. Finally, it is unknown how to measure whether political party or movement meets the criteria. Like Ivaldi, Mudde also presents the key indicators of far right that unlike the discussed theories rely on rankings and use German school experience. According to the author, the main indicators are: nationalism, xenophobia, belief in authoritarianism and a chauvinistic social programme (Mudde, 2007: 15-22). Mudde notes that if social or political group shows the first and second indicators (nationalism and xenophobia), it shares nativism. If the third (belief in authoritarianism) is added, it expresses the radical rightwing and in the case of supporting social chauvinism policy, it reaches the right-wing extremism. This typology is less rigid and more flexible. Nevertheless, it pays less attention to how to measure the levels of nationalistic or xenophobic political stances. For the author, it is possible to label any type (nativist, radical, extremist) to any political group by analyzing its manifestos and public speeches. We reckon this theory is more relevant not to newly founding, but already institutionalized political unions, while our research tries to determine political positions of emerging far right groups, so this approach will be less relevant.

As we can see, the authors are trying to formulate the features of the far right. While the German school, unlike the Anglo-Saxon experience, focuses on the distinction between radicalism and extremism, the authors of both approach agree that the understanding of the concept should include these issues: anti-system and anti-immigration sentiments, strong law and order, nationalistic and xenophobic policies. Synthesizing these basic principles, Hainsworth proposes the features of far right after empirical research (Hainsworth, 2008: 5-23). It can be argued that it is more the results of the development of existing academic literature than the attempt to create a new classification. Interestingly, the author draws on the experience of both schools and features, and on the one hand, focuses on the opposition to globalization and liberal democracy (AngloSaxon school) and on the other hand, stresses the difference between radicalism and extremism (German school). Also, Hainsworth shares the components that occur in both approaches. The author's four major criteria (features) are: foreign policy, identity policy, socio-ethical issues, neo-populism/democracy framework. It should be highlighted that it allows us to represent them as measurable indicators. For instance, foreign policy covers the attitudes towards globalization, immigration and neighborhood policy (Hainsworth, 2008: 5-23). At the same time, this approach can be used to study cases when the positions of political movements are not clear, which meets the goal of our research. Hence, we use the Hainsworth's understanding of the far right as the theoretical framework of this study.

The empirical research on this issue is one of the first in Georgia, so it is important to process the primary data. As the selected movements do not have manifestos, the understanding of their platform could only be done with a survey. Therefore, we used questionnaire in a form of face-to-face interview. This method helps us to compare re- 
spondents positions on the same issues with the same items. Interestingly, not all the movements specified the number of their members, as mostly they do not have institutionalized organizational structure and permanent members. They usually have supporters and protesters who join them during the protests. Therefore, the political positions of these movements can be examined through the permanent representatives of these groups: founding members and political leaders. Hence, we used convenience sampling: surveys with the criteria of official leader or/and founder. After that, we asked them to be tied with their deputies, active and permanent members of their movement, so snowball sampling was used. Because of the less organized structure and lack of the will to share the exact number of their members, some of these movements represented only 3 respondents (political leaders, active permanent members and founders). To ensure the same proportion, making survey with the same number of respondents was decided. Therefore, 3 members from 4 most visible movements (Georgian March, Edelweiss, Georgian National Unity, Anti-liberals) were surveyed anonymously, as some of them are underground community members.

The questionnaire is divided into 4 thematic categories (according to the theoretical framework): foreign policy, identity policy, socio-ethical issues, neo-populism/democracy framework. Table 1 shows categories and relevant indicators we set out at statements in the questionnaire.

Table 1. Criteria and indicators of the questionnaire of this study

\begin{tabular}{|l|l|}
\hline \multicolumn{1}{|c|}{ Criteria } & \multicolumn{1}{c|}{ Indicators } \\
\hline Foreign policy & $\begin{array}{l}\text { Positions on globalization, migration and neighborhood } \\
\text { (Russia, Turkey, EU, NATO), political neutrality }\end{array}$ \\
\hline Identity policy & $\begin{array}{l}\text { Positions on national, regional (Caucasian, European) } \\
\text { identity, multi-culture, Christian values }\end{array}$ \\
\hline Socio-ethical issues & $\begin{array}{l}\text { Positions on death penalty, abortion, violence over } \\
\text { women, anti-discrimination law, gender equality, social } \\
\text { chauvinism }\end{array}$ \\
\hline $\begin{array}{l}\text { Neo-populism/frame } \\
\text { of democracy }\end{array}$ & $\begin{array}{l}\text { Position of representation of general will of the people, } \\
\text { politicians and parties, political system, supremacy of law }\end{array}$ \\
\hline
\end{tabular}

Source: own elaboration.

In order to ensure diversity of political positions, the questionnaire contains 50 statements that cover 4 categories. Respondents should rate the statements on 1-5 point Likert scale, where 1 means - "strongly disagree", 2 - "disagree"; 3 - "neutral"; 4 - "agree", 5 - "strongly agree". It is important to compare positions of the movement members, as well as the average score of the different categories that allows us to determine whether respondent answers vary with different category. During processing the data, the scores 
for statements will be positioned that 5 reflects far right political position (though in the questionnaire some statements are reverse, as respondents do not consider the same number with the same positions). The results will be presented with average scores.

If this figure is between 4 and 5 in each category, we can assume that it meets with far right political positions by theoretical framework. However, this technique of research has several limitations. Firstly, it determines the positions of movement members by already formulated statements so some special opinion of a respondent can be neglected. In addition, the consistency of statements is under the question that can face the lack of validity. And last, but not least, when respondents "strongly agree" with some statements, it can be radical right position, but it is hard to determine which political stance expresses the answer "strongly disagree" on the same statement. Nevertheless, as the goal of the research focuses on characterization of the political positions of newly emerged movements, this methodology can be relevant. Taking into account that this research is the first attempt to collect the data, it has crucial importance to provide the same statements for all respondents to avoid interpretations. This technique allows us to compare movements' positions on different category, as well as between their members. Moreover, calculating Cronbach's Alfa, it can be possible to discuss about the internal consistency of the statements. As for the opposite benchmark of far right, we can present the scale as measurement of non-far right/far right political positions.

\section{Overview of contemporary politics of Georgia}

Before presenting the results of the research, for a better understanding of the context, we reckon it is essential to present a brief overview of key political paradigms of modern Georgian history. Georgia declared independence in 1991 after the collapse of the Soviet Union. This was preceded by a few years of powerful national-liberation movement. While standing on nationalistic political platform, its narrative was clearly anti-Soviet and we cannot identify it with any king of far right position. In the first half of the 1990s, on the one hand, the collapse of the Soviet centralized economy and on the other hand, the series of civil wars in the country made significant changes in the social structure of the population. In 1995-2003, the new, but soviet-experienced, government tried to established relations with the West and supported economic cooperation and 'freezing' of existing territorial conflicts with Russia. The level of poverty had been increasing and corruption had become integral part of daily life of the Georgian citizens. Although declarative nationalistic forces had been emerging from time to time, their political positions and influence were insignificant as the sustainability of the state institutions themselves were under the question (Wheatley, 2005: 114). Public dissatisfaction turned into the Rose Revolution in November 2003 when the new political group gained the constitutional majority and stressed the Euro-Atlantic integration as the only foreign policy goal of Georgia (Wheatley, 2005: 114). Following the footsteps of the democratiza- 
tion and Westernization path, the citizens who has failed to make a drastic change have been marginalized. We can assume that society was divided into winners and losers of Rose Revolution. Finally, due to authoritarian actions, the government lost public support and as a result of the 2012 parliamentary elections, for the first time in the history of independent Georgia, the government was replaced by elections.

Under the new government, the Euro-Atlantic foreign policy course was declared once again (Wheatley, 2005: 175), demonstrated by the Association Agreement with the EU, the 90-day visa-free travel to the Schengen area and joint military exercises with NATO. In addition, on every step on the Western integration path, Russia (with which Georgia has severed diplomatic relations since the 2008 Georgia-Russia war) is shifting its creeping occupation line and incorporating several Georgian villages (Coffey, 2018). Although there is a little support for pro-Russian political parties (usually non-parliamentary opposition) in Georgia, in 2018 in the constitution of the country it was still written down that "constitutional bodies should take all measures to ensure full integration into the European Union and NATO" (The Constitution of Georgia, Article 78, 1995). It can be assumed that this record was done to avoid potential threats in future.

In Georgia, where the major social-economic conditions remain the biggest challenge, the anti-discrimination law (adopted in 2014 during the process of Associate Agreement with the EU) has become controversial, as it gives equal rights and opportunities to all minorities (New anti-discrimination law: Challenges and achievement, 2014). The value-based debate started on the issue of selling/not selling agrarian land to foreigners. Initially, the Parliament of Georgia adopted the bill to protect limited land resources, though later the Constitutional Court declared it unconstitutional. Proponents of the idea (including the Georgian March that we are studying in this research) believed foreigners should not own Georgian historical lands, while opponents emphasized the necessity for investments and an open economy.

During the last two decades in Georgia (with the growing process of Europeanization), the political elite have referred to any change as synonymous with European, Western and progressive. Thus, citizens who have felt the poverty and inflation during this time are alienated, and may be opposed, from the mentioned concepts. An alternative to these empty words can connect with far right platform with supporting anti-system agenda focusing on anti-minority and anti-immigration stances. Though, as we already stressed, there have not been the vivid positions in the party spectrum so far and, therefore, for the research we have chosen political unions that are in the formation process.

\section{Results of the research}

First and foremost, to determine and provide the internal consistency of the statements, we calculated Cronbach's Alpha that is +0.7 . This allows us to present the aggregate average scores from all items. Also, the standard deviation for each movement is 
less than 0.4, which shows we can present average score for each movement aggregated their member positions. As the statements in this questionnaire are divided into 4 categories, we believe it is more appropriate initially to review the results for each category. Although it does not express each movement positions, still it shows the general trends among respondents. After that, we will compare results between selected movements.

\section{Foreign policy}

This part of questionnaire consists of propositions on globalization, immigration, neighbourhood policies and political neutrality. First of all, it should be mentioned that if the aggregate average score is in 4-5 gap, it allows us to talk about the far right political positions. Data processing revealed that the respondents generally agree $(+4.5)$ that "the process of globalization is against with national Georgian interests". The greater support is visible for the proposition that the citizenship rule should be stricter. The similar results show that the respondents clearly expressed the desire to adopt the strict migration policy. In addition, there is a strong support with the idea that increasing share of ethnic minorities in Georgia is a problem for the security of the country. If we take into account the recent demographic trends (natural growth of ethnic Georgian is decreasing), it is easier to explain why the far right position is so unanimously supported.

As we have already mentioned, the reinforcement of these sentiments can be the counter-reaction to the process of Europeanization. Thus, prepositions also covered EU-Georgia relations. Interestingly, according to the respondents, by the rapprochement process with Europe, Georgian values (+3.7) are more harmed than Georgian economy (+2.8). Such Euro-skeptic positions should be explained by cultural alienation factors rather than economic ones. However, the clear position about the given issue is not expressed by the aggregated data. The more nihilistic stance is presented on the issue of membership of North Atlantic Treaty Organization (NATO) that declared to support $(+4.3)$ the preposition that under the occupied territories, it is impossible to join this military-political organization. Despite the avowed Euro-Atlantic foreign political course, the answers of the respondents are different. In this point, questionnaire also included prepositions that measured the respondents support for political neutrality and strategic partnership with Russia (see Table 2).

Table 2. Respondent support for foreign policy directions of Georgia

\begin{tabular}{|c|c|c|c|}
\hline $\begin{array}{c}\text { Political } \\
\text { neutrality }\end{array}$ & $\begin{array}{c}\text { Strategic } \\
\text { partnership } \\
\text { with Russia }\end{array}$ & $\begin{array}{c}\text { Membership } \\
\text { of the UE }\end{array}$ & $\begin{array}{c}\text { Membership } \\
\text { of NATO }\end{array}$ \\
\hline+2.3 & +2.5 & +2.7 & +3.2 \\
\hline
\end{tabular}

Source: own elaboration. 
As it turns out, the general trend shows that membership of NATO has relatively high support, though this score is closer to the neutrality benchmark. Therefore, we assume that these groups have not yet come to the common position on this issue. However, in the context of the neighbourhood policy, at least two issues have been identified, with relatively similar positions. The first is desire to restore political relations with Russia, while the second is to perceive Turkey's policy as the threat to Georgia. Although Turkey is one of Georgia's major economic partners, Adjara (the border region of Georgia with Turkey) has significant Turkish influences in social-cultural fields too. Interestingly, political groups loyal to Russia usually portrait Turkey as the historical enemy of Georgia, stressing religious differences between the countries.

\section{Identity policy}

In this part of the questionnaire, the majority of respondents completely agreed with the statement that Georgian identity is in danger. At the same time, all of them see process of globalization as being against the national interests and identities. As we can assume, for the respondents, global political processes are one of the causes of the national identity crisis. Also, the strong link between Georgian and Caucasian or European identities was not revealed. The responses are close to the neutrality benchmark that the regional identity issue is not problematic for these political unions. Nevertheless, the issue of the religious identity is clearly outlined. The respondents believe that Christian values should be further strengthened as nowadays they are weakened $(+4.7)$. When we link this position with the citizenship rule and growth of ethnically non-Georgian population, we can assume this chain of reasons can be proxy for undermining Georgian, Christian values for given political union members.

\section{Socio-ethical issues}

In this part of the questionnaire, only a few positions of the respondents were unanimous. This concerns the priority of employing ethnic Georgians, banning the sale of agricultural land to foreigners and anti-abortion policy. First and foremost, the emphasizing the prioritization of ethnic Georgians is not grounded by general economic problems rather than manifests social chauvinism. This is also evidenced by strong opposition to sell agrarian land to foreigners. This picture reminds already tested political message in Europe which in this case sounds like: "Georgia for Georgians". The anti-abortion stance is somehow linked to necessity of reinforce Christian values that is also a trend in Western politics. This issue is related to strongly supported statements that "Christianity is superior to other religions" (+4.8) and "propaganda of Islam should be restricted" $(+4)$. The religious cleavage has two main reasons. The first one is linked to the Turkish issue, as most of the respondents believe that this country conducts policy against the Georgian interests and in this point, religion can be seen as the soft power of Turkish policy. 
The second is the statement about Asian immigrants who are incompatible with Georgian culture $(+4.2)$ in the context of their Muslim religion.

It is also noteworthy that some respondents attribute highlighting gender equality and family violence issues to Western propaganda and mass media manipulation. At the same time, they are against of free manifestation and expression of sexual minorities and are strongly opposed to civil partnership between them $(+4.8)$. These topics are related to anti-discrimination law that is seen as damageable for Georgian interests for most of the respondents. Although the stances in this part are more or less similar, there is no consensus on the issues of law and order. For instance, the death penalty and stricter laws are unresolved topics for many respondents. However, as a rule, generally European far right parties have clear positions on law and order issue.

\section{Neo-populism/framework of democracy}

The differences between the respondents' positions are clearly outlined from this part of the questionnaire. A third of them see their future activities in the legislative framework, while others do not refuse to violate the law. The results suggest that while these unions are in the formation process, radical and extremist assumptions may already be drawn that comes from German school experience. However, all of the respondents share the idea that political elite and politicians are corrupted, foreign-funded and do not express the general will of the people. At the same time, they believe that their union shares "the will of the people". These stances are linked to the neo-populism and increase the likelihood of their future participation into party politics.

We presented the average score for all respondents for each category (see Table 3 ). According to the aggregated data, the foreign policy category fails to meet 4.0-5.0 gap, while the category of identity policy is on the margin of error. However, it should be

Table 3. Average scores (from 1 to 5 ) of all respondents by categories

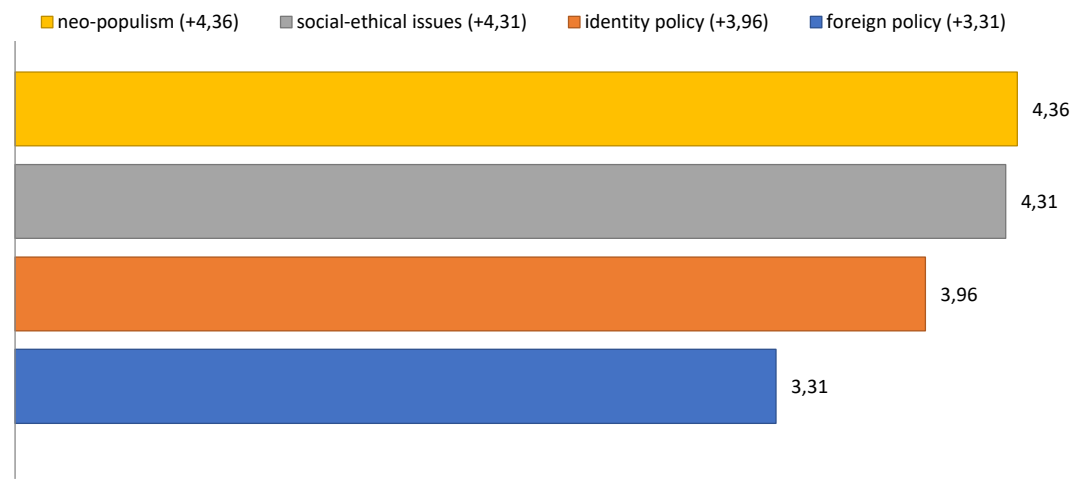

Source: own elaboration. 
noted that the average scores outlined by the members of the two unions (Edelweiss and Georgian Marsh) were above 4.0 even in these two categories. More similar results are shown with socio-ethical and neo-populism parts, average score for each union exceeded 4 and meets far right political positions.

On the other hand, different results are outlined between political unions (see Table 4). The average score of Anti-liberals is 3.3 which means its member positions are close to the neutrality benchmark according to the aggregated data from all statements. The result of Georgian National Unity almost coincides (with a deviation of only 0.1) the threshold of 4. As for Georgian Marsh and Edelweiss, their scores are in the gap of far right political platform.

It should be highlighted that results calculated both at category and political union levels show a few exceptions from the general trend. In the case of foreign policy, respondents overall reported the least radical positions. Also, in comparison to other political union members, representatives of Anti-liberals outlined more neutral attitudes towards the questionnaire statements. Due to the small number of the respondents, using the correlation coefficient is less relevant. However, it is still possible to find more or less strong links between different variables. For instance, the respondents who perceive globalization as the threat to national identity are more likely to be in favour of stricter immigration policy. Also, the more they believe the idea that Turkey is conducting disingenuous policy with Georgia, the more they support the limitation necessity of Islam propaganda.

In addition, after cross-tabulation analysis, several issues can be observed. The respondents who believe that politicians in Georgia are largely foreign-funded are more likely to support Georgia's membership in the North Atlantic Treaty Organization than joining the EU and support of the idea of political neutrality (see Table 5). Although 75\% of the respondents support the restoration of diplomatic relations with Russia, the idea of strategic partnership is still unfavourable. Generally, according to the data, it can be con-

Table 4. Average scores (from 1 to 5 ) of all respondents by political movements

चanti-liberals Georgian National Unity Georgian Marsh $\quad$ edelweiss

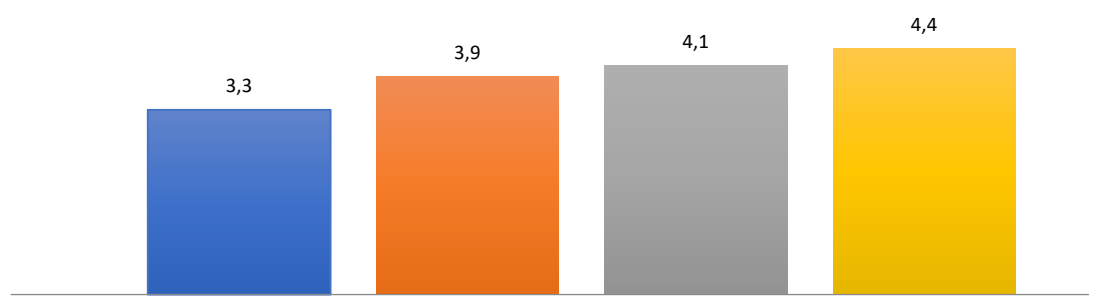

Source: own elaboration. 
Table 5. Crosstab analysis: answers on foreign policy course out of the respondents who believe that Georgian politicians are mostly foreign-funded

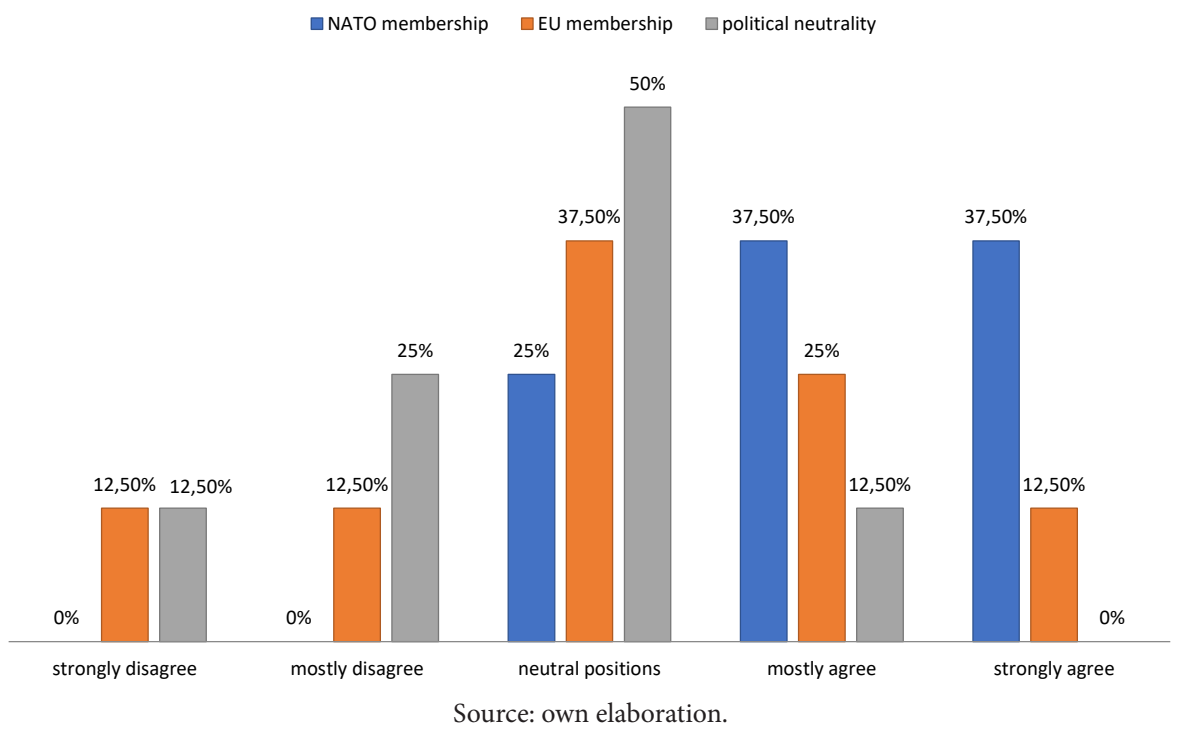

Table 6. Crosstab analysis: answers on sharing all democratic principles out of the respondents who believe in prioritization of ethnical Georgians on the workplace

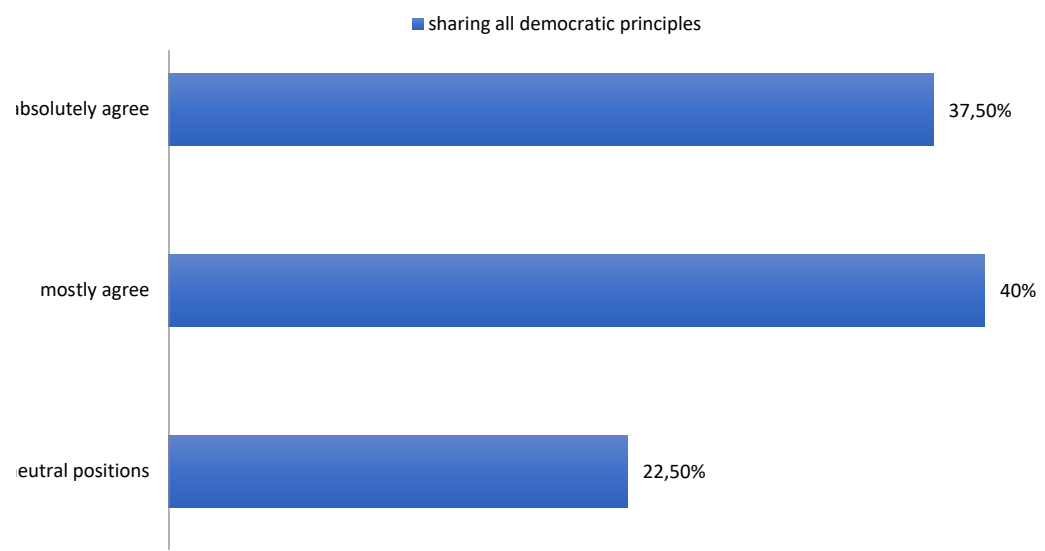

Source: own elaboration.

cluded that for these political unions foreign policy course is undetermined. Therefore, we can assume that cleavages of their politics are focused on domestic political issues.

Another observation shows on Table 6. 77,5\% of the respondents who "strongly agree" that "ethnic Georgians should be given priority at the workplace" (referring to social chauvinism), "fully" or "mostly" share all of the core principles of democracy. The explanation of these surprising results can be typical understanding of the values 
of democracy for these political union members who do not hesitate to stress the ethnicity in their homeland.

\section{Conclusions}

The goal of the study has been to determine the major features of Georgian far right movements using the European-experienced understanding of the concept. It should be mentioned that there is no consensus about the term in the academic society. Instead of the notions of radical and extremist right, we used more general term - far right. However, we provided the statement about the supremacy of law in the questionnaire. The members of Edelweiss and Georgian March are ready to violate the law and the constitution if necessary, while representatives of the Georgian National Unity and Anti-liberals declare to act in the legislative framework. Rating the respondents' statements from 1 to 5 , for each case the average score from 4 to 5 is considered to be far right political position (and the significant proportion of the respondents were exactly in this gap).

Thus, according to the aggregated data, it is possible to discuss the key political characteristics of these far right movements. First of all, it is undecided or neutral position on foreign policy both on political neutrality or partnership with Russia, EU or NATO. However, the similar stances are visible with non-friendly perception of Turkey, limitation necessity of Islam propaganda and strong link between growing number of non-ethnic Georgians and national security issues. Moreover, it includes portrayal of globalization as damaging Georgian national identity (that is neither part of the Caucasian not European) and support for a strong immigration policy with sharing the ideas of incompatibility with Georgian culture and restrictions to sale agriculture land to foreigners. Another important point is connection between Georgian identity with traditional Christian values that appear in anti-abortion, anti-sexual minority rights and gender inequality positions. The majority of respondents also support social chauvinism in the terms of prioritizing of ethnic Georgians at the workplace that can be echo of hard socio-economic problems of the country.

In addition, the respondents share the ideas that European new anti-system parties present. In particular, they perceive other politicians and political groups as corrupt, elite, foreign-funded institutions and at the same time, self-identify as the protectors of "the will and national interest of the people". This neo-populist approach suggests that surveyed political movements may become anti-system parties in the future.

This study has made it possible to identify the major features of far right groups in Georgian political reality. It allows us to develop the research into several directions. Firstly, understanding and analyzing the reasons for these political positions, if there is the link between socio-economic and demographic variables and political stances of the movement members. Secondly, how these groups are organized and structured, as well as their governance style and funding. And lastly, what kind of political positions are expressed by similar movements in other post-soviet or the Eastern Partnership countries. 


\section{Bibliography}

13 lawyers are defending the leader of National Unity (2018), https://www.radiotavisupleba. ge/a/29548800.html [access on: 7.11.2019].

Alt-Info, https://www.facebook.com/pg/altinfo01/posts/?ref=page_internal [access on: 7.11.2019].

Anti-liberal club, https://www.facebook.com/pg/ANTILIBERALURI/posts/?ref=page_internal [access on: 7.11.2019].

Coffey L. (2018), NATO membership for Georgia: In U.S. and European interest, https://www. heritage.org/sites/default/files/2018-01/SR-199_0.pdf [access on: 18.04.2019].

Eatwell R. (2003), The Extreme Right in Britain: the long role of modernization, [in:] Western Democracies and the new extreme right challenge, edit. R. Eatwell, C. Mudde, Bath.

Georgian far-right groups reach agreement about forming new political party (2019), "Democracy and Freedom Watch", 6.04.2019, https://dfwatch.net/georgian-far-right-groups-reachagreement-about-forming-new-political-party-53106 [access on: 1.05.2019].

Geostat (2019), Net Migration, https://www.geostat.ge/en/modules/categories/322/migration [access on: 20.04.2019].

Hainsworth P. (2008), The Extreme Right in Western Europe, New York.

How women are accepted into the Georgian fascist organizations and where they are forbidden to love (2018), http://tbiliselebi.ge/index.php?newsid=268453070 [access on: 7.11.2019].

Ignazi P. (1992), The Silent Counter-revolution: hypothesis on the emergence of extreme right-wing parties in Europe, "European Journal of Political Research", No. 22, pp. 3-34.

Ignazi P. (2003), Extreme Right Parties In Western Europe, Oxford.

Ivaldi G. (2004), Droties populists et extremes en Europe occidentale, Paris.

Kakachia K., Minesashvili S. (2015), Identity politics: exploring Georgian foreign policy behavior, “Eurasian Studies”, No.6, pp.172-175, DOI: https://doi.org/10.1016/j.euras.2015.04.002.

Koopmans R. (1997), Dynamics of Repression and Mobilization: the German Extreme Right in the 1990s, "Mobilization: An international Quarterly", No. 2, pp.149-164.

Member of National Unity: We are Georgian fascists (2018), https://www.radiotavisupleba. ge/a/29231623.html [access on: 7.11.2019].

Mudde C. (1996), The War of words defining the extreme right party family, "Journal of West European Politics", No. 19, p.205, DOI: https://doi.org/10.1080/01402389608425132.

Mudde C. (2007), Populist Radical Right parties in Europe, Cambridge.

Mudde C. (2017), The Populist Radical Right: A Reader, New York.

Neo-Nazis march in Tbilisi - symbol of white nationalism (2016), https://www.amerikiskhma. com/a/georgia-neo-nazis-marched-in-tbilisi-center/3528473.html [access on: 7.11.2019].

New anti-discrimination law: Challenges and achievement (2014),

https://www.transparency.ge/en/blog/new-anti-discrimination-law-challenge andachievements [access on: 21.05.2019].

Nodia G., Scholtbach A.P. (2006), The political landscape of Georgia: political parties: achievements, challenges and prospects, Delft.

Results of Public Opinion Polls in Georgia (2019), "NDI", 18.09.2019, https://www.ndi.org/publications/results-july-2019public-opinion-polls-georgia [access on: 12.04.2019].

Roth A. (2019), Georgia prepares for the first LGBT pride amid treats of violence, "The Guardian", 16.06.2019,https://www.theguardian.com/world/2019/jun/16/georgia-prepares-for-first-lgbtpride-tbilisi-amid-threats-of-violence [access on: 18.04.2019].

Rydgren J. (2005), Is extreme right-wing populism contagious? Explaining the emergence of a new party family, "European Journal of Political Research", No. 44, pp. 413-437, DOI: https://doi. org/10.1111/j.1475-6765.2005.00233.x.

Stephan A. (2018), Defining the far right in Georgia: from neo-fascists to populist parties, http://gip. ge/wp-content/uploads/2018/10/Adriana_FINAL.pdf [access on: 18.04.2019]. 
Taggart P. (1995), New Populist Parties in Western Europe, "West European Politics", No. 18, p.34, DOI: https://doi.org/10.1080/01402389508425056.

The anatomy of Georgian neo-Nazism (2018), https://www.transparency.ge/ge/blog/kartuli-neonacizmis-anatomia [access on: 20.04.2019].

The Constitution of Georgia (1995), https://matsne.gov.ge/en/document/view/30346?publication $=35$ [access on: 10.04.2019].

The EMC responds to the violence on September 27 by ultranationalist groups (2016), https:// emc.org.ge/ka/products/emc-27-sektembers-ultranatsionalisturi-jgufebis-mier-gamo vlenili-dzaladobis-fakts-ekhmianeba [access on: 7.11.2019].

Von Beyme K. (2007), Right-wing extremism in post-war Europe, "Journal of West European Politics”, No. 11, pp. 1-18, DOI: https://doi.org/10.1080/01402388808424678.

Wales O. (2017), Georgian far right nationalism and the Russian factors, "Regional Dialogue", http://regional-dialogue.com/en/georgian-far-right-nationalism-and-the-russian factor/ [access on: 10.04.2019].

Wheatley J. (2005), Georgia from National Awakening to Rose Revolution: delayed transition in the former Soviet Union, New York.

Who threatens to create the civilian guard (2019), https://netgazeti.ge/news/277032/ [access on: 7.11.2019].

Abstract:This article deals with the emerging far right movements in Georgia, where the growing Europeanization process is taking place. Therefore, it aims to determine how relevant the European-experienced understanding of the far right with the similar movement political positions is. The article presents the stances of the members of far right movements (Georgian March, Anti-liberals, Georgian National Unity and Edelweiss) on foreign and identity policy and different socio-ethical issues, also assessed the neo-populist manner and belief in supremacy of the law. The conclusion summarizes the major characteristics of these far right movements in comparative way.

Keywords: political positions, far right, Georgian politics, political movements

Article submitted: 4.10.2019; article accepted: 10.11.2019. 